\title{
Are Industries Open for Renewable Energy?
}

\author{
Edgars KUDURS ${ }^{1 *}$, Anrijs TUKULIS ${ }^{2}$, Arnis DZALBS $^{3}$, Dagnija BLUMBERGA $^{4}$ \\ ${ }^{1-4}$ Institute of Energy Systems and Environment, Riga Technical University, \\ Azenes iela 12/1, Riga, LV-1048, Latvia
}

\begin{abstract}
The progress towards climate neutrality and sustainable development of the national economy is increasingly challenging. At the European Union level, the target for renewable energy set by Directive 2018/2001 is at least $32 \%$. Industry is not only an essential part of the national economy but also a field of opportunity for increasing the share of renewable energy in the total final energy consumption balance of the country. The paper evaluates renewable energy technologies using a combination of AHP and TOPSIS methods using technical, economic, environmental, and social criteria. In order to indicate the needs, potential barriers, and position of enterprises on renewable energy, an enterprise survey is conducted. Both the survey and multi-criteria decision analysis ranks solar PV as the technology with the highest potential. The results of the survey overall show that enterprises are open to renewable energy technologies, especially if incentives such as financial support are available, for example, in the form of a grant.
\end{abstract}

Keywords - Analytic hierarchy process (AHP); enterprise survey; multi-criteria decision analysis (MCDA); renewable energy sources (RES); technique for order of preference by similarity to ideal solution (TOPSIS)

\section{INTRODUCTION}

One of the most critical sectors of the economy is the energy sector. Its main tasks are the extraction of energy resources, their processing into energy, and supply to consumers. Without energy, no other economic sector can develop. Despite the growing share of renewable energy in recent years, fossil fuels (coal, natural gas, and oil) still dominate the world's energy consumption [1].

Greenhouse gases in the industrial sector have increased rapidly in recent decades with a negative impact on climate. As the environmental, economic, and social requirements rise, the progress towards climate neutrality and sustainable development of the national economy is increasingly challenging.

In order to reduce negative impact on climate, as well as to reduce the use of fossil energy resources, European Union (EU) member states have set mandatory targets for increasing the use of RES. At the EU level, the RES target set by Directive 2009/28/EC for 2020 is $20 \%$ [2]. Based on the starting position and circumstances of each Member State, individual targets have been set, which in the case of Latvia the target is $40 \%$ by 2020 . As regards the year 2030, the target for renewable energy set by Directive 2018/2001 is at least $32 \%$ at the EU level [3], which in the case of Latvia is $50 \%$ by 2030. In addition, at the end of 2019, the European Commission presented a new, ambitious package known as the European Green Deal, which sets a target to become the first carbon-neutral continent by 2050 [4]. Carbon-

* Corresponding author.

E-mail address: Edgars.kudurs@gmail.com 
neutrality is a state where economic activity and consumption do not have a negative impact on the climate. Achieving climate neutrality is characterized by greenhouse gas balance reducing all emissions and offsetting non-reducible emissions by capturing them in plants and forests or receiving and storing emissions underground.

Climate change has become a significant issue in recent years, not only because of its environmental, but also economic and social implications. According to survey results presented in the World Economic Forum's Global Risks Report [5], climate change is shown as the number one risk by impact and number two by likelihood. However, transition to carbon-neutrality must be evaluated comprehensively (holistically) to avoid exacerbation of influences because of disordered actions. This comprehensive approach should also apply to decision-making, which is discussed in this paper in relation to the promotion of RES technologies in enterprises.

Aim of research is to identify which RES are most viable when mutually compared and determine which RES has highest potential among Latvian companies.

In Latvia, a high share of renewable energy is provided by hydropower, with a total installed capacity of $1565 \mathrm{MW}$ in 2018, and it accounts for a vast majority of the total installed capacity of renewable energy technologies for electricity generation [6].

Compared to other EU countries, the share of RES in final energy consumption in Latvia is relatively high [7]. According to 2017 data, it reached $39.01 \%$ [8]. This is mainly due to the installed hydropower plant capacity and the fact that, in Latvia, historically biomass (wood) is used as a fuel, and it is widely available [9].

Given the high share of renewable energy in Latvia, finding new opportunities to increase it is a challenge. Nevertheless, there still is potential to increase the share of RES in many sectors, including the industrial sector.

Solar energy is a RES that is available free of charge. Solar energy technologies can generally be divided into two groups: technologies for electricity generation and technologies for thermal energy generation. The conversion of solar energy into electricity takes place through PV systems. Polycrystalline modules are the most common on the market. In 2017, polycrystalline modules accounted for $60.8 \%$ of the total PV production in the world, leaving second place for monocrystalline modules with $32.2 \%$ and third place for thin-film modules with a relatively small share of $4.5 \%$ [10]. The global installed PV power capacity in 2018 was $505 \mathrm{GW}$, which makes it the third most widely used renewable energy technology [11].

Solar energy in Latvia is currently being used at a minimum. At the end of 2019, the total installed capacity of solar technologies for electricity generation was only $3 \mathrm{MW}$ [6]. In Latvia, the average global horizontal irradiation is up to $1100 \mathrm{~kW} / \mathrm{m}^{2}$ [12]. The most considerable amount of radiation is observed in the coastal zone, where the duration of sunshine reaches $1840 \mathrm{~h}$ to $1940 \mathrm{~h}$ per year [13]. As for the amount of electricity produced, one $\mathrm{kWp}$ of installed capacity in Latvia theoretically is capable of generating an average of 1022 to $1095 \mathrm{kWh}$ of electricity per year [14]. However, in order to obtain the most accurate information, each PV installation should be considered separately.

The conversion of solar energy into useful heat is realized by a solar thermal collector. Solar energy is absorbed into the solar collector, where the heat generated can be transferred to the final consumer through a heat carrier. Solar thermal collectors are divided into two groups - non-concentrating and concentrating. Non-concentrating solar thermal collectors are mainly used for space and domestic hot water heating in buildings while concentrating collectors - for process heat applications and electricity generation using steam turbines.

Wind energy is converted into useful energy using wind turbines. Wind turbines are divided into horizontal and vertical axis turbines. Another simple division of wind turbines includes 
their location - onshore and offshore wind turbines. Onshore wind turbines are located on land. The best locations to install this type of turbine include hill-tops, gaps in mountain ranges, and coastal areas. Offshore wind turbines are installed in sea and ocean areas where the wind is stronger and more constant in comparison with locations onshore. Onshore wind turbines usually are smaller than offshore wind turbines but are less expensive to establish than offshore wind turbines [15].

Wind energy potential depends on wind speed at the particular location. The average annual wind speed in Latvia is about $5 \mathrm{~m} / \mathrm{s}$ on the coast of the Baltic Sea and about 3-4 m/s on the mainland [12]. At the end of 2019, the installed capacity for wind energy in Latvia accounted for $78 \mathrm{MW}$ (145 wind turbines with different capacities), which is the third-largest RES technology after hydropower and biomass cogeneration and power plants. The theoretical potential of onshore wind energy in Latvia could be up to $1000 \mathrm{MW}$ of installed capacity, but due to various barriers, the currently estimated amount is significantly smaller [16].

Geothermal energy is thermal energy found in the depths of the Earth that can be used for heating, as well as electricity generation in tectonically active areas where higher temperatures are available. One of the advantages of geothermal energy is its independence from the weather, unlike wind and sun energy. Geothermal energy can be used in a variety of technologies, one of which is heat pumps [17].

In Latvia, the intensity of the internal heat flow of the Earth is very different in different regions. The highest groundwater temperature is in south-western Kurzeme (the Cambrian sediment temperature in this region reaches $38-62{ }^{\circ} \mathrm{C}$ at a depth of $1192-1714 \mathrm{~m}$, the Devonian sediment at a depth of $600-775 \mathrm{~m} ; 20-30{ }^{\circ} \mathrm{C}$ ) and in Jelgava (Eleja) (the Cambrian sediment temperature in this region at a depth of $1100-1436 \mathrm{~m}$ reaches $33-55^{\circ} \mathrm{C}$, the Devonian sediment at a depth of $400-584 \mathrm{~m} ; 20-30{ }^{\circ} \mathrm{C}$ ). In Latvia, the perspective area of using geothermal energy is around 15-20 thousand $\mathrm{km}^{2}$, but it significantly increases with the use of lower-temperature Devonian sediment-water for heat and hot water production by heat pumps [18]. Although geothermal energy can be used in a variety of technologies, given the situation in Latvia described above, ground source heat pump technologies that use geothermal energy for heat and hot water are the most suitable in Latvia.

Bio-energy is energy produced from biological resources (trees, shrubs, grass, animal waste, etc.). Compared to other RES, biomass is the most geographically available resource, relatively inexpensive, and can be processed into a liquid, solid, and gaseous fuel, which can further be used for the production of electricity, heat energy, and as fuel for vehicles. Biomass can be divided into traditional use and modern use, where with traditional use we understand combustion processes of wood and other forms of biomass and with modern - use of biofuel and biogas produced in biochemical and thermochemical processes [20]. In Latvia, the most widely used bio-resource is wood fuel justified by the aspect that forests cover $52 \%$ of the total land area in Latvia [9]. In 2019 the total installed capacity for biomass cogeneration and power plants, and biogas cogeneration plants was $97 \mathrm{MW}$ and $61 \mathrm{MW}$, respectively [6].

Although historically, the use of biomass has a significant place in Latvia's energy balance, in the long run, it is necessary to slowly move away or at least not increase the direct use of biomass for energy production and better to use it for higher value-added products.

\section{Methodology}

Methodology to reach aim of research is most crucial part and has significant impact on results. 
There is not one universal approach to determine relevance of RES in industries, and more than 20 research are done on subject in USA [19]. As [19] conclude in research on industries relations with RES, there are trends of stagnation in growth speed of RES in manufacturing industries in USA, and it is advised to consider type of RES used to obtain more precise results. One of the first steps of the methodology used in research is to conduct an enterprise survey. This is important given that enterprises are the ones that ultimately decide in favour of introducing RES technologies. The survey will indicate the needs, potential barriers, and position of the enterprise on the renewable energy issue as such. There are many aspects to consider when it comes to the decision-making process - for example, if a decision-maker lacks knowledge about technology, he/she may select the technology based on the most obvious aspects such as price [21]. In certain decision-making cases where a decision is based only on economic considerations (for example, lower costs) the environmental dimension (for example, lower $\mathrm{CO}_{2}$ emissions) or the social dimension (for example, jobs created) is excluded, but in order to ensure sustainable choices, all dimensions of impact must be considered [22]. In view of the above, AHP and TOPSIS methods are used to evaluate renewable energy technologies considering the multi-criteria approach. The results will allow comparing ranking by enterprises surveyed and multi-criteria decision analysis results regarding the best RES technologies.

\subsection{Enterprise Survey}

The target group of the survey is manufacturing enterprises. The survey was prepared using the online software "Typeform" and sent out to 2000 manufacturing enterprises consuming $500 \mathrm{MWh}$ or more of electricity annually. As only criteria was energy consumption, companies represent various industries. The survey is based on the following questions:

1. Are renewable energy technologies used in your company;

2. Specify which RES is/are used;

3. What limits the use of RES;

4. What would facilitate the use of RES;

5. Which three RES technologies could have the most potential in your company;

6. What is the approximate monthly electricity consumption of your company;

7. Is energy consumption one of the top three cost positions in your company;

8. Would you be interested in the results of this survey and learning more about RES technologies.

When summarizing the result of question No. 5 , in order to take into account whether the technology is indicated as the first, second or third priority, coefficients have been selected that are multiplied by the number of respondents who have indicated the specific RES technology at the respective priority level. This coefficient for first priority is 3 , for second priority -2 and for third priority -1 . The incidence of each RES technology is calculated using Eq. (1):

$$
R_{R E S}=\frac{p_{1} \cdot 3+p_{2} \cdot 2+p_{3} \cdot 1}{\sum_{n=1}^{n} p_{1} \cdot 3+p_{2} \cdot 2+p_{3} \cdot 1} \cdot 100
$$

where
$R_{\text {RES }}$
incidence of specific RES technology among respondents, \%;
$p_{1}, p_{2}, p_{3}$
n number of respondents who indicated RES technology as first priority $\left(p_{1}\right)$, second priority $\left(p_{2}\right)$ and third priority $\left(p_{3}\right)$; number of total RES technologies considered. 


\subsection{Application of AHP}

MCDA basically includes the following steps: target definition, definition of alternatives, selection of criteria, determination of their weight, and evaluation of alternatives. In this paper, AHP is used to determine the weight of the criteria and TOPSIS - for all other steps.

Four main criteria are used for alternative evaluation: technical criteria, economic criteria, environmental criteria, and social criteria - these are the criteria that characterize a decision based on the principles of sustainable development.

The first step for the calculation of criteria weights is the pairwise comparison. For this comparison, the nine-integer value scale is used as presented in Table 1. The nine-integer value scale was initially suggested by Saaty [24].

TABLE 1. SCALE FOR PAIRWISE COMPARISON [23]

\begin{tabular}{ll}
\hline Scale & Definition \\
\hline 1 & Equal importance \\
3 & Moderate importance of one over the other \\
5 & Essential or strong importance \\
7 & Very strong or demonstrated importance \\
9 & Extreme or absolute importance \\
$2,4,6,8$ & Intermediate values between the two adjacent judgments \\
\hline
\end{tabular}

Each criterion is compared to all other criteria forming the comparison matrix. In order to determine the ranks of criteria, the next step is solving the eigenvector problem. There are three methods for solving the eigenvector problem - Saaty's method, the power method, and the geometric mean method. In this case, Saaty's method is chosen, given its simplicity compared to the other two methods. The first step is a normalization of the comparison matrix - the sum of each column of the pairwise comparison matrix is calculated, and the values in the corresponding column are divided by it. The next step is the calculation of eigenvectors of each matrix row - values in each row are summed and divided by the number of criteria. The eigenvectors give the ranking (weight) of the criteria [25]. However, so that these weight values can be used with some certainty for further evaluation, it is necessary to calculate the consistency index $(C I)$ and consistency ratio $(C R)$.

\subsection{Application of TOPSIS}

TOPSIS has been used in different fields, including the evaluation of different energy generation technologies [26]. TOPSIS main benefits are the choice of an unlimited number of criteria and alternatives, a relatively simple calculation process and no need for a specific software or special programming skills. TOPSIS results allow comparing alternatives in a convenient and easily understandable way.

The target of TOPSIS analysis is to compare RES technologies in order to find technology that performs the best in terms of the criteria set. For the evaluation, six alternatives were selected: biomass technologies, solar PV panels, solar thermal technologies, technologies that use renewable part of waste as an energy source, wind technologies, and geothermal technologies.

Technologies were assessed based on four criteria: technical, economic, social, and environmental. The technical aspect includes the level of technological development, also known as technology maturity, which characterizes how advanced the technology is, i.e., 
whether there is potential for efficiency gains or whether the theoretical maximum level of technological productivity has already been reached [27]. The technical aspect also includes the feasibility of innovation, process efficiency, and energy quality, which often is expressed as reliability, which describes the ability of technology to work continuously and independently - without unforeseen damage, interruptions, and additional monitoring. Reliability is one of the most commonly used criteria in the multi-criteria analysis and has always been a topical issue in the energy sector [28]. Reliability is affected by conditions such as the quality of technical equipment, required maintenance, the type of energy source used, etc. The economic aspect includes capital investments and operational costs, as well as costs related to additional costs of replacing equipment from an occasional source of energy at a time when energy is not available. Investment costs consist of several parts (equipment costs, installation costs, other system element costs, etc.). Operation and maintenance costs are regular costs associated with the maintenance and optimal operation of technological systems. These may include, for example, regular (scheduled) maintenance, system repairs, etc. These costs are often expressed as a percentage of the total investment costs. The social aspect covers issues of increased or declining employment as well as the impact of imports. The environmental aspect is linked to increasing or reducing impact on environmental pollution and climate change, also considering the production of technological equipment. This is expressed as life cycle emissions that consider the impact at all stages of the technology, which is essential in sustainable decision making. For each criterion, its individual weight representing the importance of the criterion shall be determined. The sum of all the criteria weights shall be equal to 1 . For the TOPSIS analysis, the weight values from the AHP results were taken.

The first step using the TOPSIS method is the normalization of the decision-matrix, followed by the calculation of normalized decision-matrix and determination of the best and worst solution. The best solution corresponds to a theoretical option of the most desirable level of each criterion, while the worst solution corresponds to a theoretical option of the least desirable level of each criterion [29]. After that, the distance of each alternative from the best and worst solution is calculated in order to obtain the closeness coefficient, which is used for the ranking of alternatives.

\section{Results}

\subsection{Enterprise Survey Results}

The survey results from 146 enterprises were compiled and analysed only in aggregate form. $42 \%$ of respondents already use renewable energy technologies in their enterprises, while the majority or $58 \%$ do not.

As main key constraints for the broader use of renewable energy technologies, $33 \%$ of respondents mention other investment priorities, $26 \%$ of respondents - long payback periods, that have primary reference to costs, and $20 \%$ of respondents - constraints of existing infrastructure, which are connected with technical aspects as well as economic aspects.

Grant/subsidy is indicated as the main incentive to promote RES technologies (59\% of respondents). Apart from the availability of grants/subsidies, awareness-raising as a better understanding of technology is the second most frequently mentioned option to help increase the use of RES technologies (17\% of respondents).

$22 \%$ of respondents could not specify their electricity consumption in terms of quantity or cost, while most of the respondents could indicate both consumption and costs or at least one 
of them. The average electricity consumption in the enterprises surveyed is $312 \mathrm{MWh}$ per month, and the average electricity bill is 16075 euros per month. Nevertheless, only $29 \%$ of respondents indicate that energy consumption is among the top three cost positions in their enterprise, while for $63 \%$ of respondents, energy costs are not among the top three cost positions, and $8 \%$ of respondents cannot indicate if it is or not.

$72 \%$ of respondents are interested in receiving the results of the survey and obtaining additional information regarding RES technologies, while a relatively large proportion (28\%) answered in the negative.

Aggregated results calculated by Eq. (1) show that according to the respondents' answers, the top three RES technologies for which they see the highest potential in enterprises are solar energy for electricity, solar energy for heat energy, and biomass technologies. Figure 1 shows the rankings of all RES technologies, as proposed in the survey.

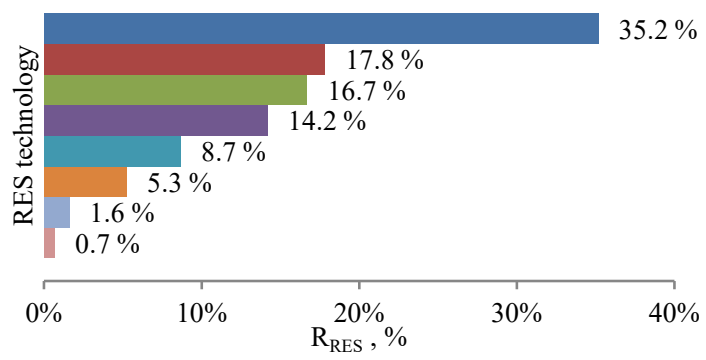

Solar energy (for electricity)
- Solar energy (for heat energy)
$\square$ Biomass (wood, straw, biogas, biofuel)
$\square$ Wind energy
$\square$ Renewable part of waste
$\square$ Geothermal energy
$\square$ Hydropower
$\square$ Tidal energy

Fig. 1. Ranking of RES technologies according to enterprise survey results.

In the authors' view, the result which ranks these three technologies as the technologies with the highest potential in view of enterprises can be linked to a better understanding of technologies. These three technologies are already the most widely used (known) among the enterprises surveyed, and some experience has been gained in their utilization. For this reason, it is possible that preference is not given to the most appropriate RES technology but in favour of the technology for which the enterprise has a sufficient amount of information.

\subsection{AHP Results}

Technical, economic, environmental, and social criteria were compared pairwise based on the author's assessment. The pairwise comparison results are shown in Table 2.

TABLE 2. AHP PAIRWISE COMPARISON MATRIX OF CRITERIA

\begin{tabular}{lllll}
\hline Criteria & Technical & Economic & Environmental & Social \\
\hline Technical & 1 & 0.3333 & 2 & 7 \\
Economic & 3 & 1 & 3 & 5 \\
Environmental & 0.5 & 0.3333 & 1 & 5 \\
Social & 0.1429 & 0.2 & 0.2 & 1 \\
\hline
\end{tabular}

After normalization of the matrix, criteria weights were calculated. Results show that economic criteria are of the utmost importance with the weight of 0.4859 ; technical criteria rank second with the weight of 0.2764 , third - environmental criteria with 0.1813 , and the fourth - social criteria with the weight of 0.0564 . 
The calculated consistency ratio value is $\mathrm{CR}=0.09351$, which conforms to the condition that $\mathrm{CR}$ must be $\leq 0.1$. It can be concluded that the comparisons are consistent and used in further calculations.

\subsection{TOPSIS Results}

Six RES technologies were evaluated using a scale from 2 to 5 , where 2 correspond to the lowest score and 5 - to the highest score and potential of the use of renewable energy in the industrial enterprises. Table 3 compiles the evaluation values in a decision-making matrix.

TABLE 3. TOPSIS DECISION-MAKING MATRIX

\begin{tabular}{lllll}
\hline \multirow{2}{*}{ RES technology } & \multicolumn{2}{l}{ Aspects } & & \\
\cline { 2 - 5 } & Technical & Economic & Social & Environmental \\
\hline Biomass & 4 & 3 & 4 & 5 \\
Solar PV panels & 5 & 4 & 5 & 4 \\
Solar thermal & 4 & 3 & 5 & 4 \\
Waste & 3 & 4 & 4 & 4 \\
Wind & 3 & 3 & 5 & 4 \\
Geothermal & 3 & 3 & 4 & 4 \\
\hline
\end{tabular}

The final result of the TOPSIS analysis is shown in Fig. 2. For the best solution, the closest alternative is solar electricity (0.94), which is due to the high valuation of this alternative, not only for the economic criterion which has the highest weight of all criteria (0.4859), but also good performance in the technical criterion which has the second-highest impact on final results. Technologies that use renewable part of waste as an energy source ranks second (0.48), however, its performance significantly lags behind solar PV. These technologies are followed by solar thermal energy (0.34) and biomass technologies (0.31) with relatively similar results. The furthest score from the best solution is for wind and geothermal energy technologies (0.16).

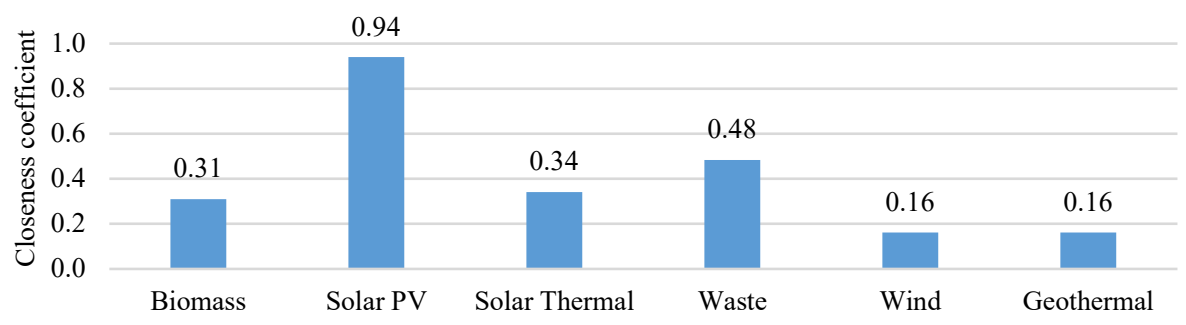

Fig. 2. TOPSIS analysis results - the ranking of RES technologies.

\section{CONCLusion}

In this paper, six RES technologies were evaluated using a combination of AHP and TOPSIS methods. The biggest impact on the final result has an economic criterion as it is directly related to the total costs and payback period, which justifies the economic viability of the project. The multi-criteria decision analysis at the selected criteria ranks solar PV as 
the best performing technology for enterprises. Also, according to the survey, solar PV received the highest rank as the technology with the greatest potential in the opinion of enterprises.

Considering that the total installed solar energy capacity currently installed in Latvia is insignificant in comparison with other RES technologies, the result, which both after multicriteria decision analysis and in the opinion of enterprises, puts solar PV as a priority technology, is favourable for policy development support. Given the barriers identified in the survey that limit the use of RES in enterprises (other investment priorities, long payback periods, constraints of existing infrastructure), it is necessary to develop appropriate policy measures to overcome these barriers. It is important that enterprises have access to complete information on RES technologies and financial instruments, as well as opportunities to receive in-depth expertise and advice. The results of the survey overall show that enterprises are open to renewable energy technologies, especially if incentives as financial support are available, for example, in the form of a grant. However, there are also a large number of respondents who are not interested in the possibilities of introducing such technologies in their enterprise.

As pointed out in [30], ideally, if more than one method can be used, since often a method change causes a bigger difference in the results obtained than the change of the user of the method, so further work on this issue could involve evaluation of RES technologies using another multi-criteria decision analysis method as well as selecting the most appropriate and the most important evaluation criteria for the decision-maker as Strantzali and Aravossis [30] emphasize that the evaluation criteria should be selected based on the specifics and objectives of the project/case being evaluated.

Another direction for further work includes the development and evaluation of policy measures to facilitate the realization of the industry's potential for greater use of RES.

\section{ACKNOWLEDGEMENT}

The research is funded by the Ministry of Economics of the Republic of Latvia, project “Assessment of Latvia's renewable energy supply-demand economic potential and policy recommendations", Project No. VPP-EM-2018/AER-1-0001.

\section{REFERENCES}

[1] Data \& Statistics - IEA [Online]. [Accessed 09.05.2020]. Available: https://www.iea.org/data-andstatistics?country $=$ WORLD\&fuel=Energy\%20supply\&indicator=CoalProdByType

[2] Directive 2009/28/EC of the European Parliament and of the Council of 23 April 2009 on the promotion of the use of energy from renewable sources and amending and subsequently repealing Directives 2001/77/EC and 2003/30/EC. Official Journal of European Union 2009:L 140/16.

[3] Directive (EU) 2018/2001 of the European Parliament and of the Council of 11 December 2018 on the promotion of the use of energy from renewable sources. Official Journal of European Union 2018:L 328/82.

[4] European Commission. Communication From The Commission To The European Parliament, The European Council, The Council, The European Economic And Social Committee And The Committee Of The Regions The European Green Deal COM/2019/640 final. Brussels: European Commission, 2019.

[5] The Global Risks Report 2020 | World Economic Forum, 2020 [Online]. [Accessed 27.04.2020]. Available: https://www.weforum.org/reports/the-global-risks-report-2020

[6] Central Statistical Bureau of Latvia. ENG090. Elektriskā jauda un saražotā elektroenerğija no atjaunīgiem energoresursiem (Electric power and electricity produced from renewable energy sources) [Online]. [Accessed 03.09.2020]. Available:

http://data1.csb.gov.lv/pxweb/lv/vide/vide_energetika_ikgad/ENG090.px/table/tableViewLayout1/ (in Latvian) 
[7] European Environmental Agency. Share of renewable energy in gross final energy consumption in Europe - European Environment Agency. 2019 [Online]. [Accessed 13.03.2020]. Available: https://www.eea.europa.eu/data-andmaps/indicators/renewable-gross-final-energy-consumption-4/assessment-4

[8] Cabinet of Ministers. Par Latvijas Nacionālo enerǵētikas un klimata plānu 2021.-2030. gadam. (On the Latvian National Energy and Climate Plan 2021-2030 year). Riga: Cabinet of Ministers, 2020.

[9] Meža platība Latvijā turpina pieaugt - pērn tie bija 52 \% (Forest area in Latvia continues to grow - last year they were 52\%), 2019. [Online]. [Accessed 13.03.2020]. Available: https:/www.lsm.lv/raksts/zinas/latvija/meza-platiba-latvijaturpina-pieaugt--pern-tie-bija-52.a325062/

[10] Fraunhofer ISE. Photovoltaics Report. Freiburg: Fraunhofer Institute for Solar Energy Systems, 2019.

[11] REN21 - 2019 Global Status Report. Paris: REN21 Secretariat, 2019.

[12] Briede A. Klimats Latvijā - Nacionālā Enciklopēdija (Climate in Latvia - National Encyclopedia), 2019. [Online]. [Accessed 12.01.2020]. Available: https:/enciklopedija.lv/skirklis/26052-klimats-Latvijā (in Latvian)

[13] Blumberga A., et al. Atjaunojamās elektroenerğijas akumulācija (Accumulation of renewable electricity.). Riga: RTU, 2015.

[14] Global Solar Atlas 2.0. [Online]. [Accessed 12.01.2020]. Available: https://globalsolaratlas.info/map

[15] Letcher T. M. Wind Energy Engineering: A Handbook for Onshore and Offshore Wind Turbines. Elsevier, 2017. https://doi.org/10.1016/B978-0-12-809451-8.00001-1

[16] Āboltiņš R. Vēja enerǵijas izmantošanu ietekmējošo faktoru analīze un iespējamie risinājumi (Analysis of factors influencing wind energy use and possible solutions.). 2019. (in Latvian)

[17] IRENA. Geothermal energy [Online]. [Accessed 13.01.2020]. Available: https://irena.org/geothermal

[18] LVG̣MC. G̦eotermālie resursi (Geothermal resources) [Online]. [Accessed 12.05.2020]. Available: https://www.meteo.lv/lapas/geologija/zemes-dzilu-resursi/perspektivie-resursi/geotermalie-resursi/geotermalieresursi?id=1488\&nid=496 (in Latvian)

[19] Ezici B., Egilmez G., Gedik R. Assessing the eco-efficiency of U.S. manufacturing industries with a focus on renewable vs. non-renewable energy use: An integrated time series MRIO and DEA approach. Journal of Cleaner Production 2020:253:119630. https://doi.org/10.1016/j.jclepro.2019.119630

[20] IRENA. Bioenergy [Online]. [Accessed 15.02.2020]. Available: https://www.irena.org/bioenergy

[21] Jaffe A. B., Stavins R. N. The energy-efficiency gap What does it mean? Energy Policy 1994:22(10):804-810. https://doi.org/10.1016/0301-4215(94)90138-4

[22] Shmelev S. E., Van Den Bergh J. C. J. M. Optimal diversity of renewable energy alternatives under multiple criteria: An application to the UK. Renewable and Sustainable Energy Reviews 2016:60:679-691. https://doi.org/10.1016/j.rser.2016.01.100

[23] Maletič D., et al. Analytic Hierarchy Process Application in Different Organisational Settings. Applications and Theory of Analytic Hierarchy Process - Decision Making for Strategic Decisions. InTechOpen, 2016. Available from https://www.intechopen.com/books/applications-and-theory-of-analytic-hierarchy-process-decision-making-forstrategic-decisions/analytic-hierarchy-process-application-in-different-organisational-settings

[24] Saaty T. L. A scaling method for priorities in hierarchical structures. Journal of Mathematical Psychology 1977:15(3):234-281. https://doi.org/10.1016/0022-2496(77)90033-5

[25] Cabala P. Using the Analytic Hierarchy Process in Evaluating Decision Alternatives. Oper. Res. Decis. 2010:20(1):523.

[26] Lee H. C., Ter Chang C. Comparative analysis of MCDM methods for ranking renewable energy sources in Taiwan. Renewable and Sustainable Energy Reviews 2018:92:883-896. https://doi.org/10.1016/j.rser.2018.05.007

[27] Haddad B., Liazid A., Ferreira P. A multi-criteria approach to rank renewables for the Algerian electricity system. Renewable Energy 2017:107:462-472. https://doi.org/10.1016/j.renene.2017.01.035

[28] Wang J. J., et al. Review on multi-criteria decision analysis aid in sustainable energy decision-making. Renewable and Sustainable Energy Reviews 2009:13(9):2263-2278. https://doi.org/10.1016/i.rser.2009.06.021

[29] Mulliner E., Malys N., Maliene V. Comparative analysis of MCDM methods for the assessment of sustainable housing affordability. Omega 2016:59(B):146-156. https://doi.org/10.1016/j.omega.2015.05.013

[30] Strantzali E., Aravossis K. Decision making in renewable energy investments: A review. Renewable and Sustainable Energy Reviews 2016:55:885-898. https://doi.org/10.1016/j.rser.2015.11.021 